\title{
Effect of Organic Spray on Growth and Yield of Amaranthus dubius var. Co - 1
}

\author{
A. Nithya Devi*, M. Madhu Priya, S. Monika, N. P. Yazhini, N. Switha and R. Nivedha
}

Department of Vegetable Science, Horticultural College \& Research Institute for Women Tiruchirappalli - 620 027, India

*Corresponding author

\begin{abstract}
A B S T R A C T
Vegetables form an indispensable part of the daily diet, particularly in India. Out of the leafy vegetables, amaranthus is the most popular vegetable consumed by people all over India. In the present day situation organically grown vegetables are gaining importance owing to increased health

\section{Keywords}

Amaranthus dubius

- Variety Co-1 -

organic sprays -

FAA - EAA -

Vermiwash

\section{Article Info}

Accepted:

18 May 2020

Available Online:

10 June 2020 consciousness among the people and free of pesticide residue. Organic manures play a key role in sustaining crop growth and productivity Use of foliar formulations is gaining importance in crop production owing to its quick response in plant growth. Foliar feeding has proved to be the fastest way of curing nutrient deficiencies and boosting plant performances at specific physiological stages. An experiment was undertaken to assess the influence foliar application of organic liquid manures prepared on the growth, yield and quality of amaranthus at Horticultural College and Research Institute for Women, Tiruchirappalli. In this study, eight treatments viz., Foliar spray of vermiwash (5\%), composite manure of groundnut cake + neem cake + poultry manure (1:0.5:0.5), egg amino acid (EAA $-0.2 \%$ ), fish amino acid (FAA-0.1\%), cowpea sprouted extract (2\%), PPFM (2\%), urea (2\%) and Control were compared. All the bio inputs tried for foliar spray recorded significantly higher yield and yield components and effective than urea and control. The highest shoot length $(24.50 \mathrm{~cm})$, number of leaves $(20.41)$, leaf area $\left(150.35 \mathrm{~cm}^{2}\right)$, Magnesium $(126.22 \mathrm{mg} / 100 \mathrm{~g})$ and calcium content $(390.00 \mathrm{mg} / 100 \mathrm{~g})$ was observed in the plants treated with FAA $(0.2 \%)$ at the time of harvest. FAA has been identified as promising organic spray for enhanced amaranthus growth and yield probably due to the production of phytohormones. This study demonstrates that the use of organic sprays viz., FAA, EAA and Vermiwash could be used as a valuable organic liquid fertilizer for better yield from Amaranthus and also without the harmful effects of chemical fertilizers. Increase in Fish consumption results in waste production which can be reutilized to reduce the negative impact on environment.
\end{abstract}

\section{Introduction}

Amaranthus grows in short duration, quick response to manures and fertilizers, high yielding, easy to cultivate and has wide adaptability to diverse agro-climatic situations makes it as a favourite crop to farmers. Amaranth belongs to the $\mathrm{C} 4$ plant group which is distinguished by high photosynthesis productivity. Belonging to family Amaranthaceae, it has three times more calcium and vitamin B than spinach leaves as well as twenty times more iron than lettuce (Bradtke, 2013).

Agricultural sector is facing the daunting challenge to feed the rapid burst in population by applying chemical fertilizers. Applications of chemical fertilizers have robbed the soil fertility and have resulted in health and 
environmental hazards. Organic waste does not contain toxins or carcinogenic materials like other chemical fertilizers and are found to improve the soil structure, water holding capacity, microbial biomass, and nutrient availability (Joong, 2011). Hence, the alternative way is to reduce the use of inorganic fertilizers by recycling the organic wastes as fertilizers. This will pave the way for sustainable solid waste management and agriculture.

Organic manures play a key role in sustaining crop growth and productivity and this is very important in vegetable cultivation. Use of foliar formulations is gaining importance in crop production owing to its quick response in plant growth (Linda, 2007). Foliar feeding has proved to be the fastest way of curing nutrient deficiencies and boosting plant performances at specific physiological stages. Organic liquid fertilization is considered as a viable means for enhancing crop production both in conventional and modern production system. Fishery is one of the major sectors of agriculture which could solve this problem but demands a great concern for the management and conservation of environment. India is the second largest supplier of fish in the world after China, with a tremendous 11 fold leap from 0.75 million tonnes in 1950 to 9.6 million tonnes by 2012 13 (Spreij, 2004).

Nearly $75 \%$ of the total weight of the fish was generated as solid waste in the form of gut, head, skin, bones, fins and frames after processing. The fish wastes rich in nitrogen, potassium, phosphorus and trace minerals (Ghaly et al., 2013) can serve as raw material for the production of many nutritive and nonnutritive products. Fermentation process converts the solid substrates in to simple molecules with the help of microbes. It is one of the promising technologies which convert the fish waste in to useful organic manure, an expensive resource for agriculture without the formation of fusty smell (Zynudheen et al., 2008). Utilization of biodegraded fish waste products as liquid fertilizer, "Fish Amino Acid" is an age old practice (Nene, 2006). At present there is no validated recommendation on a suitable organic foliar spray schedule for growing amaranth organically.

In this context, an experiment was undertaken to assess the influence foliar application of organic liquid manures prepared on the growth, yield and quality of amaranthus. Hence, considering the scope, need and practical utility the research work entitled "Effect of organic foliar spray on growth and yield of Amaranthus dubius var. Co-1" was taken up. The focal of this study was to assess the efficacy of different bio input products as a foliar fertilizer for Amaranthus dubius.

\section{Materials and Methods}

The present investigation on mulaikeerai (Amaranthus dubius Mart ex Thell.) was carried out to study the effect of organic foliar spray on the growth and yield of amaranthus variety Co- 1 at the experimental farm of the Horticultural College and Research Institute for Women, Tiruchirapalli during 2017 in field experiment. A brief account of the materials used and methodologies followed in the experiment are presented here.

\section{Plant growth conditions}

Amaranthus seeds variety Co-1 were procured from Tamil Nadu Agricultural University, Coimbatore and raised under field condition at the instructional farm at Horticultural College and Research Institute for Women, Tiruchirappalli. The experiment was laid out in Randomised Block Design with eight treatments and three replications. The field was prepared to a fine tilth and form beds of 2 $\mathrm{x} 1 \mathrm{~m}$ size. 
The beds were irrigated before and after sowing and at 3 days intervals after germination. The basal application of farmyard manure along with full $\mathrm{P}, \mathrm{K}$ and half nitrogen was applied uniformly for all treatments. Organic liquid manures were prepared and applied to the crop as foliar spray to substitute the fertilizers used for top dressing. In this study, eight treatments viz, Foliar spray of vermiwash (5\%), composite manure of groundnut cake + neem cake + poultry manure (1:0.5:0.5), egg amino acid (EAA $-0.2 \%$ ), fish amino acid (FAA- $0.1 \%$ ), cowpea sprouted extract (2\%), PPFM (2\%), urea $(2 \%)$ and Control were compared.

Observations on growth characters like shoot length, root length, number of leaves, leaf area, yield parameters like total fresh weight, total dry weight production and biochemical attributes like chlorophyll stability index, magnesium and calcium content were recorded.

\section{Preparation of cowpea sprouted extract}

Cowpea seeds are soaked overnight and incubated in a wet cloth for $12 \mathrm{~h}$ to enable sprouting. A $100 \mathrm{~g}$ of sprouts were ground in a mixer - grinder by using ice cubes from $100 \mathrm{~mL}$ of water. The ground substances were squeezed through cloth bag and $100 \mathrm{ml}$ of extract to prepare extracts of $100 \%$ concentration was obtained and used as a foliar spray.

\section{Preparation of composite manure}

The extracts of composite manure prepared by mixing groundnut cake, neemcake and poultry manure (in 1:0.5:0.5) Mix with 5 times of water and liquid extract was collected after 7 days. Foliar application of these liquid manures as substitute to nitrogen for top dressing in amaranthus enhanced plant height, number of leaves per plant, crop yield and Vit C content. The nutrient content present in composite manure was 0.26:0.08:0.16 of N, P and $\mathrm{K}$ respectively.

\section{Preparation of egg amino acid}

Mix equal quantity of jaggery semi solid cold water syrup with 500 gms of jiggery and mix it with lemon - egg - jaggery solution and keep it under closed container for another 10 days. After 20 days, extract the egg amino acid booster. EAA is rich in proteins and vitamins. The dosage is 1 or $2 \mathrm{ml}$ of EAA with 1 litre of water.

\section{Preparation of fish amino acid}

Fish Amino Acid (FAA) is an effective organic liquid fertilizer. Its making is very easy and cheap. It's made from fish waste $(1 \mathrm{Kg})$ and solid jaggery $(1 \mathrm{Kg})$. Slice solid jaggery and cut the fish into small pieces. Take an air tight plastic jar/bottle and put the mixture fill up to $2 / 3$ volume of jar mix this well and store in a cool dry place. Keep it away from direct sun light. Need to be kept for 30 days. Then filter the waste and remove it, take the liquid portion and save upto 3 months.

The recommended dose of FAA for foliar spay is $1 \%$. Morphological traits like the average shoot length, root length and leaf areas were measured. The Biochemical attributes like Chlorophyll content (SPAD value), Calcium content (mg/100g) and Magnesium content (mg/100g) was determined by versanate method (Katz and Navone,1964) and yield traits like fresh weight (g), Dry weight (g) were observed.

Statistical analysis variance was done using the Agres statistical software (1994, Pascal International Software Solutions) and conclusions were drawn from the results obtained from the package. 


\section{Results and Discussion}

The results of the study carried out to assess the influence of organic spray on growth, yield and quality of Amaranthus dubius under field experiment are detailed here under. The highest shoot length and leaf area was observed in the plants treated with Fish Amino Acid $(0.2 \%)$ at 20th day after sowing and at the time of harvest. Table 1 shows the significant increase in shoot length of amaranthus after 10 days of FAA application.

The increased plant growth is mainly due to the improvement moisture availability and nutrients especially nitrogen. This result is consistent with that of (Atakora et al., 2014) who has observed higher rate of plant growth in carrot after the application of FAA. Availability of dry matter from rich nutrients, higher light interception due to increased leaf area and high photosynthetic activity leads to an increase in the plant growth. The effects of Fish Amino Acid on the leaf area of the Amaranthus plants are shown in Table 1 .

The increase in leaf area could be due to the enhanced availability of the nutrients particularly nitrogen which promotes the leaf area and function, increased cell division and elongation. The results obtained are in accordance with the report in brinjal, chilli and tomato (Roy et al., 2013). FAA treated plants had increased shoot length, root length, fresh and dry plant weight than control (Table 1 and 3 ).

Increased activity of the plant growth promoting rhizobacteria also enhances the growth and proliferation of the roots by increasing the availability of nitrogen (Boukcim et al., 2006) and by the production of auxins (Kloepper et al., 1989). Fish waste contains important minerals like calcium, phosphorus, potassium, sodium, magnesium, zinc, manganese and copper (Ghaly et al.,
2013) similar to the nutritive value as fish. The amount of protein, amino acids, calcium and phosphorus were found to be increased after the fermentation of fish waste (Vijayan et al., 2009). Amino acid is one predominant forms of nitrogen, used by the plants for their growth (Jones et al., 1994). FAA spray increased the thickness of xylem and phloem which facilitates the translocation, conduction and storage of photosynthates and thereby increase in yield of brinjal (Thendral et al., 2014). Amaranthus plants treated with PPFM (2\%) showed the maximum root length at $20^{\text {th }}$ DAS and at the time of harvest respectively. This enhancement in growth and biomass in Amaranthus treated with PPFM may be due to the excretion of plant growth hormones like auxins and cytokinins by PPFM that influence germination and root growth and play critical role in a plant's response to water stress (Long, 2000). PPFM bacterial accumulation cause auxins production that led to develop of leaf area.

Production of auxins can effect positively on leaf cells wall to become soft, so that leaf area be expanded (Taiz and Zeiger, 1998).Similarly, the increase in the vegetative growth of the plant attributed to the increase in the yield of a crop. Release of growth promoting substances like IAA and GA, proliferation of beneficial organisms in the phyllosphere leads to control of plant pathogens in addition to growth promotion.

The plants treated with vermiwash (5\%) recorded the highest chlorophyll stability Index at the time of harvest. This is in accordance with the findings of Venkatramana et al., (2009). Foliar spray of vermiwash increased the chlorophyll content and yield of mulberry. Sivasubramanian and Ganeshkumar (2004) recorded that vermiwash contains enzymes, earthworm secretions which stimulate the growth and yield of the crop through foliar spray. 
Table.1 Effect of organic sprays on Plant Height $(\mathrm{cm})$, root length $(\mathrm{cm})$ and Leaf area $\left(\mathrm{cm}^{2}\right)$ of Amaranthus dubius

\begin{tabular}{|c|c|c|c|c|c|c|c|}
\hline \multirow[t]{2}{*}{ Treatments } & \multicolumn{3}{|c|}{ Shoot Length $(\mathrm{cm})$} & \multicolumn{3}{|c|}{ Root Length (cm) } & \multirow{2}{*}{$\begin{array}{c}\text { Leaf area } \\
\left(\mathrm{cm}^{2}\right)\end{array}$} \\
\hline & $\begin{array}{l}10^{\text {th }} \\
\text { DAS }\end{array}$ & $\begin{array}{l}10^{\text {th }} \\
\text { DAS }\end{array}$ & $\begin{array}{l}20^{\text {th }} \\
\text { DAS }\end{array}$ & $\begin{array}{l}\text { 10 }^{\text {th }} \\
\text { DAS }\end{array}$ & $\begin{array}{l}20^{\text {th }} \\
\text { DAS }\end{array}$ & $\begin{array}{c}\text { At } \\
\text { harvest }\end{array}$ & \\
\hline $\mathrm{T}_{1}-$ Vermiwash & 9.80 & 4.33 & 7.95 & 9.54 & 17.50 & 21.00 & 136.43 \\
\hline $\mathrm{T}_{2}$ - Composite manure & 10.10 & 4.54 & 8.33 & 10.00 & 18.20 & 22.00 & 142.95 \\
\hline $\mathrm{T}_{3}-$ Fish Amino Acid & 10.00 & 4.6 & 7.19 & 8.63 & 20.41 & 24.50 & 150.35 \\
\hline $\begin{array}{l}\mathrm{T}_{4} \text { - Cowpea sprout } \\
\text { extract }\end{array}$ & 10.40 & 4.44 & 8.14 & 9.77 & 17.91 & 21.50 & 139.68 \\
\hline $\mathrm{T}_{5}-$ Egg Amino Acid & 10.50 & 4.17 & 7.65 & 9.18 & 16.00 & 20.20 & 131.23 \\
\hline $\mathrm{T}_{6}-\mathrm{PPFM}$ & 9.80 & 3.92 & 9.28 & 11.13 & 15.83 & 19.00 & 123.44 \\
\hline $\mathrm{T}_{7}-$ Urea & 10.50 & 4.20 & 7.00 & 8.40 & 15.41 & 18.50 & 120.19 \\
\hline $\mathrm{T}_{8}-$ Control & 10.30 & 4.00 & 5.68 & 6.81 & 12.00 & 15.00 & 97.46 \\
\hline SEd & 0.14 & 0.05 & 0.69 & 0.12 & 0.23 & 0.28 & 1.80 \\
\hline $\mathrm{CD}(0.05)$ & NS & NS & 1.45 & 0.26 & 0.48 & 0.58 & 3.76 \\
\hline
\end{tabular}

Table.2 Effect of organic sprays on Chlorophyll content (SPAD value), calcium content (mg), magnesium content (mg) of Amaranthus dubius at the time of harvest

\begin{tabular}{|l|c|c|c|}
\hline \multicolumn{1}{|c|}{ Treatments } & SPAD value & $\begin{array}{c}\text { Calcium } \\
\text { content }(\mathbf{m g})\end{array}$ & $\begin{array}{c}\text { Magnesium } \\
\text { content(mg) }\end{array}$ \\
\hline $\mathrm{T}_{1}$ - Vermiwash & $\mathbf{3 9 . 1 0}$ & 387.50 & 119.07 \\
\hline $\mathrm{T}_{2}$ - Composite manure & 36.46 & 385.00 & 124.74 \\
\hline $\mathrm{T}_{3}$ - Fish Amino Acid & 37.20 & $\mathbf{3 9 0 . 0 0}$ & $\mathbf{1 2 6 . 2 2}$ \\
\hline $\mathrm{T}_{4}$ - Cowpea sprout extract & 35.27 & 376.25 & 121.91 \\
\hline $\mathrm{T}_{5}$ - Egg Amino Acid & 33.14 & 353.50 & 114.54 \\
\hline $\mathrm{T}_{6}$ - PPFM & 31.17 & 332.50 & 107.73 \\
\hline $\mathrm{T}_{7}$ - Urea & 30.35 & 323.75 & 106.90 \\
\hline $\mathrm{T}_{8}$ - Control & 24.61 & 312.50 & 102.23 \\
\hline $\mathrm{SEd}$ & 0.85 & 4.87 & 0.004 \\
\hline $\mathrm{CD}(0.05)$ & 1.78 & 10.13 & 0.009 \\
\hline
\end{tabular}


Table.3 Effect of organic sprays on fresh weight and dry weight of Amaranthus dubius at the time of harvest

\begin{tabular}{|l|c|c|}
\hline \multicolumn{1}{|c|}{ Treatments } & Fresh weight(g) & Dry weight(g) \\
\hline $\mathrm{T}_{1}$ - Vermiwash & 2205.00 & 551.25 \\
\hline $\mathrm{T}_{2}$ - Composite manure & 2310.40 & 577.60 \\
\hline $\mathrm{T}_{3}$ - Fish Amino Acid & $\mathbf{2 4 3 0 . 0 0}$ & $\mathbf{6 0 7 . 5 0}$ \\
\hline $\mathrm{T}_{4}$ - Cowpea sprout extract & 2257.50 & 564.37 \\
\hline $\mathrm{T}_{5}$ - Egg Amino Acid & 2121.00 & 530.25 \\
\hline $\mathrm{T}_{6}-$ PPFM & 1995.00 & 498.75 \\
\hline $\mathrm{T}_{7}-$ Urea & 1942.50 & 485.62 \\
\hline $\mathrm{T}_{8}-$ Control & 1575.20 & 393.80 \\
\hline $\mathrm{SEd}$ & 29.23 & 7.30 \\
\hline $\mathrm{CD}(0.05)$ & 60.80 & 15.20 \\
\hline
\end{tabular}

All the bio inputs tried for foliar spray recorded significantly higher yield and yield components and effective than urea and control. The highest shoot length $(24.50 \mathrm{~cm})$, leaf area $\left(150.35 \mathrm{~cm}^{2}\right)$, Magnesium $(126.22$ $\mathrm{mg} / 100 \mathrm{~g})$ and calcium content $(390.00$ $\mathrm{mg} / 100 \mathrm{~g})$ was observed in the plants treated with FAA $(0.2 \%)$ at the time of harvest.

FAA has been identified as promising organic spray for enhanced amaranthus growth and yield probably due to the production of phytohormones. This study demonstrates that the use of organic sprays viz., FAA, EAA and Vermiwash could be used as a valuable organic liquid fertilizer for better yield from Amaranthus and also without the harmful effects of chemical fertilizers. Increase in Fish consumption results in waste production which can be reutilized to reduce the negative impact on environment.

\section{References}

Atakora,K., K.Agyarko and E.K. Asiedu. 2014. Influence of grasscutter, chicken manure and NPK fertilizer on the physical properties of a chromic luvisol, growth and yield of carrot, International Journal of plant and Soil Science, 3(2): 197-2014.

Boukcim,H., L.Pages and D.Mousain. 2006. Journal of Plant Physiology, 163; 12931304

Bradtke, B. 2013. Growing Amaranth as a food plant. http://www. Tropical permaculture.com/amaranth-plant.html.

Ghaly.A.E., Ramakrishnan.V.V, M.S.Brooks, S.M.Budge and D. Dave, 2013. FishProcessing Wastes as a Potential Source of Proteins, Amino Acids and Oils: A Critical Review, Journal of Microbiology Biochemical Technology., Vol.5(4.): 107-129

Jones, D.L., P.R.Darrah. 1994. Amino-acid influx at the soil root interface of Zea mays L.and its implications in the rhizosphere, Plant Soil, 163: 1-12.

Joong,K.K. 2011. Cost-Effectiveness of Converting Fish Waste into Liquid Fertilizer. FishAquat Sci 14(3):230-233.

Katz, H., and R.Navone. 1964. Method of simultaneous determination of calcium and magnesium. Journal of American water works association, 56; 121-123.

Kloepper,J.W., R.Lifshitz and M.N.Schroth, 
1988.Pseudomonas inoculants to benefit plantproduction, ISI Atlas Science Animal Plant Science., Vol.1:60-64.

Linda,S. 2007. Compost tea: Examining the sciencebehind the claims. Puyallup Research and extension centre, Washington State University. Pp.8-10.

Nene.Y.L., 2006. Kunapajala - a liquid organic manure of antiquity, Asian Agri- History, Vol.10:315-321.

Roy, M., S. Kamar, A. Debsarkar, P.K.Sen and J. Mukherjee. 2013. Application of rural slaughterhouse waste as an organic fertilizer for pot cultivation of solanaceous vegetables in India, International Journal of Recycling of Organic waste in Agriculture, 2: 1-11.

Sivasubramanian, K. and M. Ganeshkumar. 2004. Influence of vermiwash on the biological productivity of marigold. Madras Agric. J., 91: 221-225.

Sprei.j,M., 2004. National Aquaculture LegislationS Overview, India. National Aquaculture Legislation Overview (NALO) Fact Sheets. In: FAO Fisheries and AquacultureDepartment (Online). Rome.

http://www.fao.org/fishery/legalframew ork/nalo_india/en.

Thendral, H.B., P. Sudhalakshmi and A. Geetha. 2014. Influence of gunapaselam, a liquid fermented fish waste on growth characteristics of Solanum melongena. Journal of Pharmaceutical Research, 6(12): 58-66.

Venkatramana, P., B. Narasimhamurthy, J. V. Krishnarao and C.K. Kamble. 2009. Efficacy of foliar spray of verminwash and cow dung wash on biochemical and yield of mulberry, Karnataka Journal of Agricultural Science, 22(4): 921-923.

Vijayan, Hena and Imelda, Joseph and R. Paulraj, R .2009. Biotransformation of tuna waste by co-fermentation into an aquafeed ingredient, Aquaculture Research, 40. pp. 1047-1053.

Zynudheen.A.A., R. Anandan and K.G. Ramachandran Nair, 2008, African Journal of Agriculture Research,Vol.3: 379-38.

\section{How to cite this article:}

Nithya Devi. A., M. Madhu Priya, S. Monika, N. P. Yazhini, N. Switha and Nivedha. R. 2020. Effect of Organic Spray on Growth and Yield of Amaranthus dubius var. Co - 1. Int.J.Curr.Microbiol.App.Sci. 9(06): 1227-1233. doi: https://doi.org/10.20546/ijcmas.2020.906.151 